\title{
BIPOLAR PLATES FOR ELECTROLYZERS AND FUEL CELLS - HOW INNOVATION MANAGEMENT IS AS A BASIS FOR SUCCESS THESE COMPONENTS
}

\author{
Thorsten Hickmann $1 \square$ (iD \\ ${ }^{1}$ Eisenhuth GmbH and Co. KG, Osterode, Germany
}
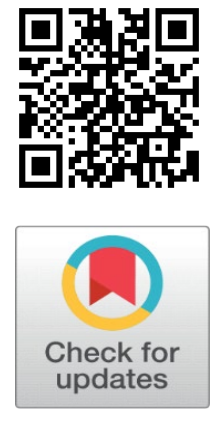

Received 1 September 2021

Accepted 15 September2021

Published 13 December 2021

\section{CorrespondingAuthor}

Thorsten Hickmann,

t.hickmann@eisenhuth.de

DOI 10.29121/IJOEST.v5.i6.2021.247

Funding: This research received no specific grant from any funding agency in the public, commercial, or not-for-profit sectors.

Copyright: (C) 2021 The Author(s). This is an open access article distributed under the terms of the Creative Commons Attribution License, which permits unrestricted use, distribution, and reproduction in any medium, provided the original author and source are credited.

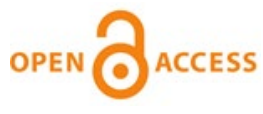

\section{ABSTRACT}

An almost abrupt change in attitude towards applications in the field of renewable energies has emerged in recent months, both among decision-makers in politics and in companies. Communication From the Commission to The European Parliament (2019) In particular, the topic of hydrogen production by electrolysis plays an eminently important role. In water electrolysis, water is split into its constituent $\neg$ parts hydrogen and oxygen using electrical energy. The resulting hydrogen is of interest to future energy systems for a number of reasons, including the fact that hydrogen can serve as a storage medium for electrical energy from renewable energy conversion systems such as photovoltaic or wind turbines. Höh (2017).

Keywords: Electrolyzer, Fuel Cell, Tianium Plates, Bipolar Plates, Innovation Management, Innovation

\section{INTRODUCTION}

Polymer electrolyte membrane water electrolysis (PEMEL) is considered particularly suitable for this type of application. In PEMEL, the water to be split is fed via so-called porous transport layers to the catalyst layer where the water splitting takes place. These porous transport layers must ensure the outward transport of the water, the outward transport of the produced gas, and the electrical contacting of the electrode. Höh (2017)

While a few years ago the topic of liquid metal injection molding made a furor and became established in some industrial sectors, the technologies presented here to produce composite materials from metallic powders has been able to establish itself in the energy storage media, i.e., especially in hydrogen production. Hickmann (2008).

Here Innovation process and technology plays an imminent role.

\section{THE ROLE OF INNOVATIONS}

Innovations are an important driver for changes in processes. But what actually are innovations? As most persons use it, the word innovation shows that the criterion of novelty is a central feature. It is necessary to determine the perspective from which the novelty of a service, on a second step a new business or a turnover is a result of innovation.

A very important feature to distinguish an innovation from an invention 
is - as already shown - the strong desire to exploite the innovation that meanst to turn it to turnover. on a company level. So, when the invention is coming to establish in processes and products in a company, then the invention has turned to an innovation introduces Kaschny et al. (2015).

In addition, innovations are much more focussing on the process, whereas the innovation ist mostly product-focussed. In order to undertand the process steps as a basis for innovation, different scientific models help to visualize this process on a company level. Models aim to map tasks that are typical for a certain process phase and thus enable a targeted use of methods. Bell (2002)

Together with innovations, innovation management is an important aspect. What is understood by this? Innovation management is understood as the targeted control and "design of innovation activities in a company "Leonard-Barton and Kraus (2002). It requires a well-organized structur and focussed company-activities aimed at the successful introduction of the innovation as a new porduct into the market, i.e., for the customers. Innovation management means a bunch of actions of strategic and operational tasks for planning, organizing and controlling innovation processes and for creating the necessary operational framework conditions. Leonard-Barton and Kraus (2002)

The following worksteps are among the core tasks of innovation management:

- Definition of innovation goals and strategies

- Planning, management as well as control of innovation processes

- Establishment and maintenance of an information system as the basis for targeted innovation control

- Establishing an organizational structure and „development frame for the growth of innovation Leonard-Barton and Kraus (2002).

But an innovation is no guarantee of success. On the contrary, there are a large number of risks that can lead to an innovation not being successful. The risks involved can be seen in Figure 1. Gaubinger et al. (2014).

The multitude of risks virtually demands that prudent innovation management be carried out.

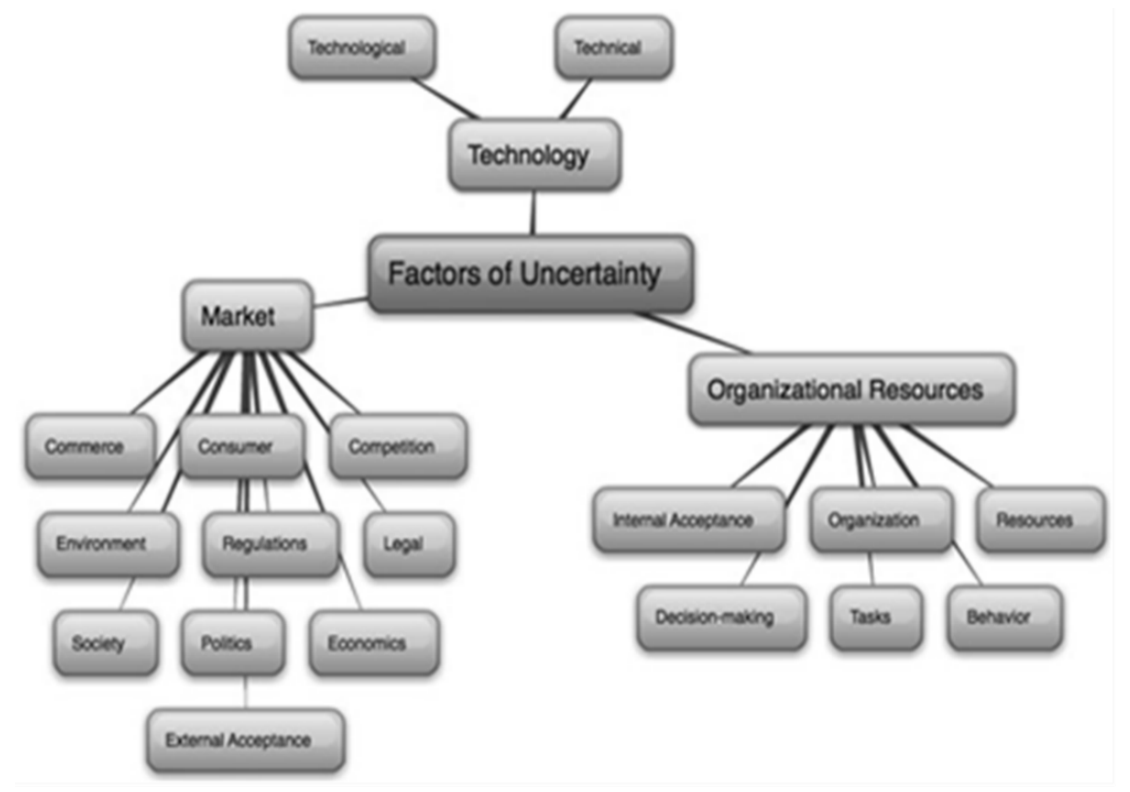

Figure 1 Fakotes of uncertainty Hughes (2002) 
The current development in the field of renewable energies shows that, in addition to the above-mentioned factors of uncertainty, the time dimension is extremely important. While the novelty of the innovation was already given in the past, an enormous market potential has now been opened up due to a new perception and the changed framework conditions. Hughes (2002)

\section{THE INNOVATION: PRODUCTION OF ENDLESS PLATES MADE OF TITANIUM}

To which area does this apply? In particular, the new development of bipolar fuel cell plates and bipolar electrolyser plates should be mentioned here.

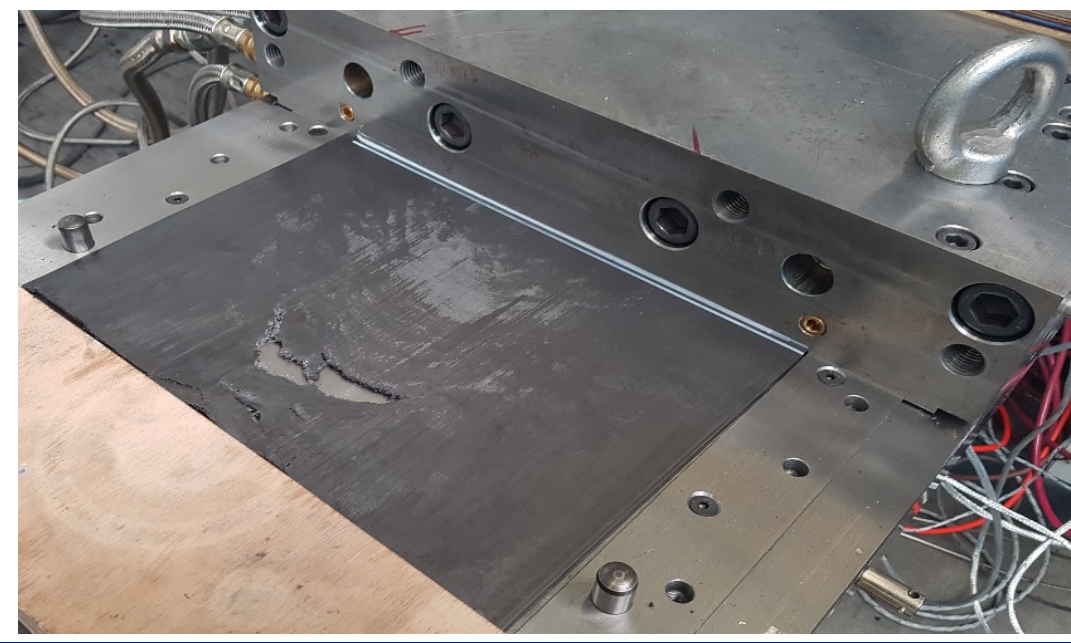

Figure 2 Extrusion process

By means of a revised process, plates for electrolysis and fuel cells can now be produced with a material thickness of less than $1 \mathrm{~mm}$.

The idea was developed several years ago, but due to the changed framework conditions the topic has now received much more attention and demand.

The next step is the extrusion process with the die shown in Figure 2. Here it is important that the temperature control is very homogeneous. Hickmann (2021) This should also be investigated in advance. After the extrusion process, the melt must be cooled and, if necessary, smoothed. Figure 3 shows a corresponding smoothing unit.

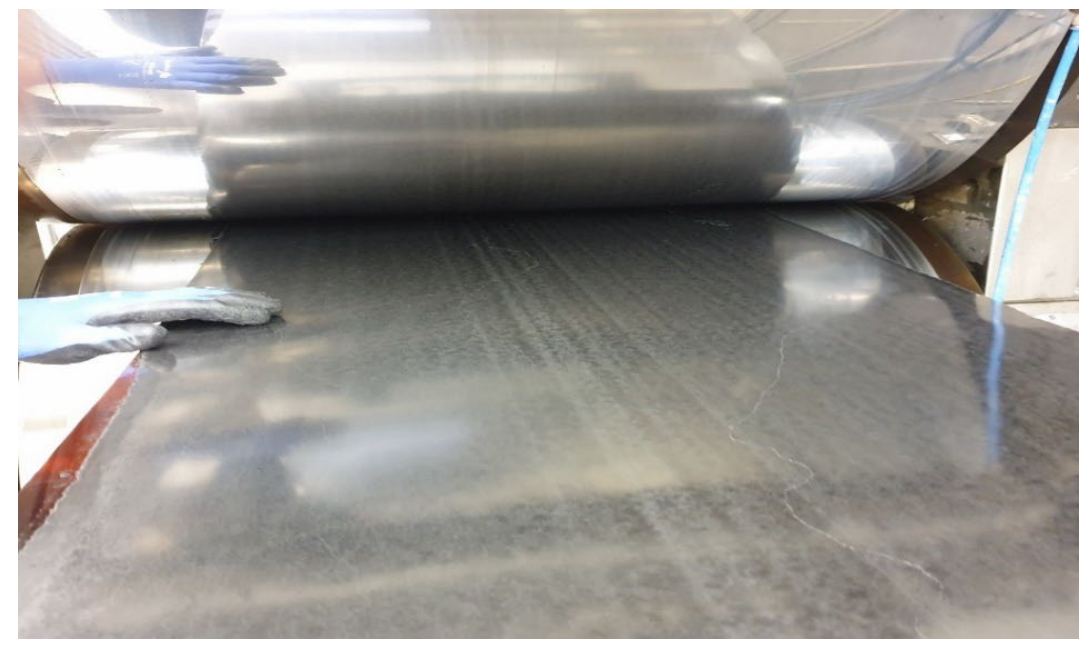

Figure 3 Smoothing unit after extrusion die and cooling section in the extrusion process 
Figure 3 shows that temperature control is a decisive factor not only in the distribution block, but also in the extrusion cooling phase and in the calender. With these process steps, it is possible to produce suitably homogeneous titanium composite plates. The plate thickness can be varied between 2 and $5 \mathrm{~mm}$ according to the tool (Figure 2). Plates with a thickness of about one millimetre require an additional process step, namely that of the smoothing unit. Hickmann (2021)

\section{SUMMARY}

The role of the energy transition has now reached all industrialised nations of the world. Several paths are being taken - and hydrogen production plays an important role here. The capital costs of the electrolysers play a role in future hydrogen production that should not be underestimated. In the electrolyzers, the bipolar plates are the most frequently used component next to the membranes and thus also contribute significantly to the total costs. Cost-effective production is therefore eminently important. This is where the new process comes in.

A continuous production of the plates is possible. In the process, it is also possible to vary the permeability of the plates. Thus, both impermeable and permeable plates are possible. The latter are particularly interesting for PEM electrolysis.

The expenses incurred here were incurred as part of the "Titanium-PorousHybrid" project. The project is funded by the state of Lower Saxony via the N-Bank under the funding code ZW 3 85116052, for which the project partners would like to express their thanks.

\section{REFERENCES}

Communication From The Commission To The European Parliament, The European Council, The Council, The European Economic And Social Committee And The Committee Of The Regions : The European Green Deal, Brussels, 11.12.2019.

Danoiel Bell (2002) On the Threshold of New Communication Technology, in: Hard Manager: Innovation Management, Vol. 1, New York.

Dorothy Leonard-Barton, William A. Kraus (2002) The introduction of new technologies, in: , in Hard Manager: Innovation Management, vol. 1, New York.

Dorothy Leonard-Barton, William A. Kraus (2002) The introduction of new technologies, in: , in Hard Manager: Innovation Management, vol. 1, New York.

Dorothy Leonard-Barton, William A. Kraus (2002) The introduction of new technologies, in: , in Hard Manager: Innovation Management, vol. 1, New York.

Everett C. Hughes (2002) What can research and development actually achieve, in: Hard Manager: Innovation Management, Vol. 1, New York.

Everett C. Hughes (2002) What can research and development actually achieve, in: Hard Manager: Innovation Management, Vol. 1, New York.

Hickmann T. (2008) Plastic applications in PEM fuel cells. VDI Reports, No 2035. 81$83 \mathrm{p}$

Höh, M (2017) Porous transport layers for polymer electrolyte membrane water electrolysis, Jülich, p. 3.

Höh, M (2017) Porous transport layers for polymer electrolyte membrane water electrolysis, Jülich, p. 3. 
Kurt Gaubinger, Michael Rabl, Scott Swan, Thomas Werani (2014): Innovation and Product Management - A Holistic and Practical Approach to Reducing Uncertainty, Springer Verlag, Heidelberg, 2014. Retrieved from https://doi.org/10.1007/978-3-642-54376-0

Martin Kaschny, Matthias Nolden, Siegfried Schreuder (2015): Innovationsmanagement im Mittelstand - Strategien, Implementierung, Praxisbeispiele; Springer Verlag, Wiesbaden. Retrieved from https://doi.org/10.1007/978-3-658-02545-8

Thorsten Hickmann, (2021) Thorsten Derieth: Duennere Bipolarplatten fuer Brennstoffzellen, in Kunststoffe, 6/2021, Munich 2021, p. 60-63

Thorsten Hickmann, (2021) Thorsten Derieth: Duennere Bipolarplatten fuer Brennstoffzellen, in Kunststoffe, 6/2021, Munich 2021, p. 60-63. 